\title{
RESENHA
}

\section{REFLETINDO A PRÁTICA DOCENTE: INSUBORDINADOS CRIATIVOS}

\author{
REFLECTING THE PRACTICE TEACHING: \\ INSUBORDINATE CREATIVE
}

D' AMBROSIO, B. S.; LOPES, C. E. Trajetórias profissionais de educadoras matemáticas. Campinas, SP: Mercado de Letras, $1^{a}$. Ed, 2014. 111p.

Anielle Glória Vaz COELHO* Simone Nunes Vieira GARCIA**

O livro Trajetórias Profissionais de Educadoras

Matemáticas, de Beatriz Silva D' Ambrósio e Celi Espasandin Lopes, é o primeiro volume da Coleção Insubordinação Criativa. No que se refere às autoras,

\footnotetext{
* Graduada em Matemática (licenciatura). Especialista em Educação Inclusiva. Mestranda em Ensino de Ciências e Matemática pela Universidade Federal de Uberlândia (FAMAT/UFU). E-mail: anielle_vaz@hotmail.com

** Graduada em Matemática (licenciatura). Especialista em Supervisão e Inspeção Escolar. Mestranda em Ensino de Ciências e Matemática pela Universidade Federal de Uberlândia. (FAMAT/UFU). E-mail: simonegarcia05@gmail.com
} 
Beatriz Silva D'Ambrósio Silva é doutora em Educação Matemática pela Indiana University e, atualmente, é professora Titular de Educação Matemática na Miami University de Ohio. Já Celi Espasandin Lopes é doutora em Educação pela Faculdade de Educação da UNICAMP e, até a presente data, professora Titular do Programa de Pósgraduação em Ensino de Ciências e Matemática da Universidade Cruzeiro do Sul.

O objetivo das responsáveis pela coleção é oferecer aos professores, independentemente de serem da área de matemática ou não, uma profunda reflexão da sua prática docente, na condição de insubordinados criativos, ou seja, docentes que se permitem burlar regras que Ihes são impostas em prol de um maior aproveitamento de seus alunos.

No livro, as autoras fazem uma análise das falas de nove professoras do Ensino Básico, sem relação alguma entre si e que foram entrevistadas isoladamente, mediante conversas espontâneas. A justificativa de terem optado por 
professoras ocorre pelo fato de a maioria dos profissionais docentes desse nível de ensino ser mulher.

A leitura do livro é extremamente agradável e de fácil compreensão. As autoras conseguem captar a atenção dos leitores ao relatar experiências vivenciadas pelas protagonistas da obra, que são professoras que se permitem fazer educação matemática no Ensino Básico, de forma a serem capazes de cometer atos de insubordinação durante a sua prática docente, com o objetivo, segundo as autoras, de gerar aprendizagem e autorrealização dos alunos.

O livro compõe-se de 111 páginas, dividido em nove capítulos onde são feitas as análises de narrativas das entrevistadas, iniciadas por melodias de músicas brasileiras. Para finalizar a obra, são apresentadas as referências que estruturaram o trabalho e uma breve exposição da carreira profissional das autoras, introduzida por um poema de Clarice Lispector.

A obra foi prefaciada por Ubiratan $D^{\prime}$ Ambrosio e apresentada por Antonio Vicente Marafioti Garnica. Tais 
apreciações funcionam como um convite aos leitores para se aventurarem nas práticas de ensino exitosas de algumas professoras, relatando, de forma sucinta, o que vem a ser insubordinação criativa e que a proposta das autoras em escrever um livro com análise de um conjunto de narrativas já deva ser considerado um ato de desobediência criativa. Logo após, no capítulo introdutório, as autoras descrevem as afinidades existentes entre elas, que se evidenciaram na elaboração do presente trabalho, bem como os estudos realizados por alguns autores que discutem as insubordinações criativas, intitulado por elas como "Vou te contar...".

No segundo capítulo, denominado "Nunca um barco à deriva", as autoras abordam um pouco do contexto histórico vivenciado pelo país durante a ditadura militar, quando se exercia um controle rigoroso sobre as produções e as ideias humanas, fosse ao campo educacional, cultural ou artístico. Na educação brasileira, essa época foi marcada pela desvalorização da carreira docente, o afastamento de professores de algumas instituições e qualquer organização 
da classe profissional. Esses motivos, segundo as autoras, levaram tais profissionais a exercer suas insubordinações de forma criativa e camuflada e que propiciaram a elas refletir sobre as formas distintas de criação desenvolvidas pelos diferentes profissionais.

No terceiro capítulo, chamado "Protagonistas de suas histórias", são apresentadas as educadoras que subsidiaram a obra. Com efeito, o capítulo retrata os profissionais que realizam constantes reflexões acerca da sua prática pedagógica e que exercem a profissão de professor com muito amor e emoção, segundo as autoras. Ainda nessa seção, é abordada a importância do papel da mulher ante a construção da sociedade e descrita à formação profissional de cada uma daquelas que foram entrevistadas.

Todas as nove profissionais são professoras que ministram aulas em escolas públicas e privadas de cidades do interior de São Paulo, em diferentes níveis da Educação Básica. 
No quarto capítulo, intitulado "Harmonia e descompasso", é levantada uma discussão das relações de interação entre as professoras e os gestores, mencionados pelas protagonistas em suas narrativas, bem como são relatadas algumas ações de insubordinação criativa cometidas pelas professoras durante a sua prática docente, decorrentes ora da cumplicidade e da harmonia, ora do confronto ou descompasso. É tratada a importância do convívio entre aqueles que se fazem presentes no processo educacional, como gestores, professores e colegas de profissão.

Já o quinto capítulo, "Amarras e tessituras", as autoras analisam as narrativas das professoras participantes, ao descreverem os atos avaliativos adotados por elas na sua prática, assim como seus dilemas, conflitos e decisões que evidenciam novas compreensões sobre os instrumentos de avaliação, atribuição de notas ou conceitos; sobre a comunicação de resultados aos gestores e pais; e sobre o envolvimento dos alunos no processo. Nesse tema, é tratada também a questão do erro em 
Educação Matemática como sendo algo positivo, uma forma de diagnóstico sobre quais são as dificuldades demonstradas pelos alunos; um momento de investigação e reflexão, para que o professor possa estruturar o seu trabalho, a fim de aprofundar as construções matemáticas dos alunos.

Durante a exposição do sexto capítulo, intitulado "Rupturas e delineamentos", é abordada a questão do currículo padronizado e linear proposto pelas instituições de ensino. Tal programa priva os alunos de adentrarem em um mundo de descobertas e de ressignificados, desconsiderando o contexto sociocultural, as emoções e anseios dos educandos, assim como a diversidade nas práticas escolares. Os atos de insubordinação cometidos pelas nove professoras levaram-nas a acolher as individualidades dos estudantes.

Em "Divergências e concordâncias", sétimo capítulo, as autoras relatam a importância das interações pessoais que nomeiam tal ponto da obra. Dessa forma, esse momento do livro possui o objetivo de compreender a 
construção de conhecimento como processo coletivo, pelo qual se compartilham as elaborações mentais marcadas pela cumplicidade, pelo saber ouvir e pelo saber argumentar sobre os caminhos pedagógicos a serem percorridos. Nesse tema, as professoras que se submeteram às entrevistas relataram as práticas pedagógicas aplicadas, envolvendo modelagem matemática e tecnologias que geraram construções matemáticas importantes por parte dos seus alunos.

O oitavo capítulo recebe o nome "Âncoras e velas içadas" porque, segundo as autoras, 0 fato de as protagonistas da obra envolverem-se em processos de formação continuada e participarem de grupos de estudos e pesquisas, com perspectivas colaborativas, viabilizou, às docentes, uma motivação e um novo olhar para a construção de conhecimentos sobre o processo de ensino aprendizagem. Os caminhos foram úteis para serem gestoras das suas práticas de ensino sendo capazes de levantar âncora e içar velas, tomando controle, assim, da sua própria navegação. 
No último capítulo, "Por um final que se faça princípio", as escritoras mencionam que o objetivo da obra foi o de compartilhar algumas ideias, as idas e vindas, pensamentos, o repensar sobre a formação dos professores, sobre a educação das crianças, o papel dos gestores, da escola, dos pais e reviver a história da ditadura militar, que direcionou a massificação da educação e da cultura científica, bem como o contentamento em se poder realizar o trabalho discutido no livro.

Posteriormente, são apresentadas as referências que subsidiaram o trabalho e um pouco das trajetórias profissionais das autoras, em forma de finalização, intitulada "Sobre as autoras".

Durante a leitura do livro percebeu-se o interesse das autoras em se descrever de forma poética, concisa, objetiva e sem desviar do objetivo proposto, em realizar uma análise das narrativas das professoras que se submeteram à investigação e se propuseram a compartilhar suas angústias e incertezas presentes nas suas experiências docentes. 
A leitura do livro é recomendada a todos os profissionais que estejam envolvidos no processo de ensino aprendizagem, especialmente, aos professores que se permitem aventurar em casos de violação de regras, muitas vezes, impostas por pessoas que não possuem o menor conhecimento da realidade vivenciada pelo docente. As autoras se propõem, de forma convicta e digna, a romper paradigmas em benefício de uma melhor aprendizagem dos seus alunos e que, por vezes, nos servem como exemplo de profissionais.

\section{REFERÊNCIA}

D' AMBROSIO, Beatriz Silva; LOPES, Celi Espasandin. Trajetórias profissionais de educadoras matemáticas. Campinas, SP: Mercado de Letras, 1a. Ed, 2014. 111p. 